\title{
WEALTH AND DEBT HOMOPHILY, GENDER EQUALITY, AND RELATIONSHIP STABILITY
}

\author{
Alicia Eads, University of Toronto* \\ Lauren Griffin, Cornell University \\ Laura Tach, Cornell University
}

\begin{abstract}
Although the relative economic standing of romantic partners influences relationship stability, previous family scholarship has largely overlooked the role of wealth and debt, two distinct economic characteristics with important implications for social stratification. We test how asymmetric accumulation of wealth and debt between partners influences marital and cohabitation stability based on gender norms, economic independence, and financial strain perspectives. Using data from the 1996-2008 panels of the Survey of Income and Program Participation (SIPP), we find support for the economic independence perspective as both femaleand male wealth-dominant couples are at an increased risk of dissolution over wealthhomophilous couples. However, for married couples, female wealth-dominant couples are significantly less stable than male-dominant couples. For cohabiting couples, heterophily is less consequential and there is little difference between male and female-dominant couples. Asymmetric holdings in debt relate differently to stability than asymmetry in wealth.
\end{abstract}

Keywords: Cohabitation, Family Economics, Dissolution

THIS IS A DRAFT. DO NOT QUOTE OR CIRCULATE WITHOUT AUTHOR PERMISSION.

\footnotetext{
ALICIA EADS is a Postdoctoral Fellow in the Department of Sociology at the University of Toronto, Toronto, ON, CA. LAUREN GRIFFIN is a Doctoral Candidate in the Department of Sociology at Cornell University, Ithaca, NY, USA. LAURA TACH is an Associate Professor of Policy Analysis and Management at Cornell University, Ithaca, NY, USA. The authors would like to thank the helpful commenters at the 2018 Eastern Sociological Society Annual Meeting. In addition, the research was supported by the President's Council of Cornell Women Affinito-Stewart Grants Program and by grant number AE00102 from the U.S. Department of Health and Human Services, Office of the Assistant Secretary for Planning and Evaluation (ASPE), which was awarded by the Substance Abuse and Mental Health Services Administration (SAMHSA). Its contents are solely the responsibility of the authors and do not necessarily represent the official views of ASPE or SAMHSA. *Direct correspondence to Alicia Eads, University of Toronto, Department of Sociology, 725 Spadina Avenue, Toronto, ON M5S 2J4, CA; alicia.eads@utoronto.ca.
} 


\section{INTRODUCTION}

Cohabiting and married partners tend to be similar on a range of culturally relevant factors, from race to religion (Blackwell, 1998; Blackwell \& Lichter, 2004; Kalmijn, 1991; Schoen \& Wooldredge, 1989). On economic dimensions, such as workforce participation and earnings, traditional theories of gender specialization predict less similarity between partners (Becker, 1974, 1981; Parsons, 1949). However, scholars working from an economic inequality perspective have found increasing similarity among partners along economic dimensions in contexts of high inequality (Dahan \& Gaviria, 2001; Fernáandez et al., 2005; Han, 2010; Heaton \& Mitchell, 2012; Mare, 1991; Schwartz, 2013; Torche, 2010). While homophilous tendencies and assortative mating structure relationship formation, the consequences of similarity along economic dimensions for relationship stability are less clear (Schwartz, 2013 p. 463-464).

Wealth and debt are central dimensions of economic stratification, but they have only recently been incorporated into family dynamics research (Charles, Hurst, \& Killewald, 2013; Eads \& Tach, 2016; Schneider, 2011). Wealth is an important resource shaping family wellbeing (Fisher et al., 2016; Keister, 2000; Oliver \& Shapiro, 1995; Rauscher, 2016). Debt, or access to credit, can be another key resource, although difficulty repaying debt is a source of financial strain (Conger \& Elder, 1994; Dew, 2007; Drentea, 2000). Notably, wealth, debt and current income are not interchangeable measures, as families with relatively high income may also be highly leveraged with few assets or vice versa (Keister \& Moller, 2000).

In this paper, we use longitudinal data from the 1996-2008 panels of the Survey of Income and Program Participation (SIPP; http://www.census.gov/sipp) to adjudicate between three theoretical perspectives on how the joint distribution of partners' wealth influences relationship stability. The gender norms perspective suggests that, among different-sex couples, the most 
stable family wealth distribution would be one in which the male partner has more wealth than the female partner, conforming to traditional norms regarding gender roles. The economic independence perspective suggests that dissimilar holdings, no matter whether the male or the female partner holds more, would contribute to greater instability because it reduces the costs of divorce. Finally, the financial strain perspective theorizes that wealth and certain forms of debt reduce familial financial strain and thus contribute to stability; asymmetrical holdings should not matter, conditional on total financial resources. We analyze whether the influences of wealth and debt differ for cohabiting and marital relationships and distinguish different types of assets and debts.

\section{BACKGROUND}

\section{Homophily and Relationship Stability}

In relationships, "[s]imilarity breeds connection" (McPherson, Smith-Lovin, \& Cook, 2001, p. 415). As the expansive literature on assortative mating has shown, socio-cultural similarity contributes to romantic connections and the formation of relationships (see Schwartz, 2013 for a review). How this similarity between partners shapes the stability of the relationship is less clear. Dissimilarity on culturally relevant characteristics — such as race, religion, and education — is generally associated with greater relationship instability (Blackwell \& Lichter, 2004; Bratter \& King, 2008; Heaton, 2002; Joyner \& Kao, 2005; Kalmijn, de Graaf, \& Janssen, 2005; Schwartz, 2010; Tzeng, 1992; Zhang \& Van Hook, 2009). However, the consequences of economic homophily for relationship stability is more mixed. Economic similarity between partners may shape relationship dynamics differently depending upon the relative importance of traditional gender roles, economic independence, and financial strain. In the following sections, we consider 
each of these perspectives and their implications for how asymmetrical accumulation of wealth and debt might influence relationship stability. We then discuss the relevance of these theories for cohabiting relationships. Table 1 summarizes the hypotheses generated from each perspective.

\section{[Table 1]}

\section{Gender Norms}

Traditional specialization theories of the family posit that specialization yields financial benefits and enhances solidarity by increasing partners' mutual dependence (Becker, 1981; Parsons, 1949). This theory was most notably challenged by Oppenheimer (1997) and more recently, scholars have argued that the specialization and trading model is based on outdated conceptions of gender roles (Sayer \& Bianchi, 2000) because younger couples now consider egalitarian marriages to be the ideal (Gerson, 2009; Pedulla \& Thebaud, 2015). Nevertheless, studies examining the effect of wives' and husbands' relative income on marital stability have found considerable empirical support for this perspective (Cherlin, 1979; Bertrand, Kamenica, \& Pan, 2015; Heckert, Nowak, \& Snyder, 1998; Jalovaara, 2003; Rogers, 2004; Teachman, 2010). In particular, nontraditional specialization —-women out-earning their husbands—-has a destabilizing effect (Bertrand et al., 2015; Brines \& Joyner, 1999; Kalmijn, Loeve, \& Manting, 2007). This pattern is consistent with Killewald's (2016) argument that while the female homemaker expectation has declined, the male breadwinner expectation has not. Men may view wealth accumulation, in addition to income, as a key aspect of fulfilling that role. For example, 
men see providing their families with a house and funding children's education as central to their role as fathers (Townsend, 2010).

When applied to wealth, the gender norms perspective suggests that couples in which the male partner has greater asset holdings would be the most stable, and that couples in which the female partner does would be the least stable, with homophilous couples falling in between. The expectation from the gender norms perspective regarding debt is less clear. It may be that men can more acceptably use debt than women to meet their families' consumption needs, allowing them to satisfy the male-breadwinner role (Baek \& Hong, 2004). To the extent that use of credit fulfills the male breadwinner role, greater debt accumulation by the male partner may not increase the risk of dissolution but greater accumulation by the female partner may.

\section{Economic Independence}

In marriages where partners are economically independent, the costs of divorce are lower. Early incarnations of exchange theory and Becker's (1981) specialization and trading model focused on wives' economic independence when considering relationship stability. More recently, researchers have emphasized the fact that men also face potential economic costs from dissolution and thus economic independence is a factor in their decisions to maintain or end relationships. When either partner has little to gain economically from a relationship and the financial ability to exit it, he or she is more likely to do so (Dechter, 1992; Heckert et al., 1998; Ruggles, 1997; Sayer et al., 2011; Schoen et al., 2002; South 2001; Teachman, 2010). This perspective suggests that partners with dissimilar asset accumulation have less stable relationships. Unlike the gender norms perspective, it does not matter whether the female or the male partner holds more wealth. 
Similarly, asymmetrical debt accumulation is likely to increase the risk of dissolution regardless of gender. Studies examining partners' spending habits suggest that marital strain results from negative perceptions of the partner's habits in relation to one's own (Britt et al., 2008). Amato and Rogers (1997) found that perceptions of one's spouse handling money poorly are a strong predictor of divorce. This suggests that asymmetry in debt holdings will increase the risk of dissolution, no matter the gender of the partner with more debt. Further, homophilous levels of debt could be indicative of joint investment, which may be a signal of particularly committed couples (Addo \& Sassler, 2010; Treas, 1993).

\section{Financial Strain}

The financial strain perspective suggests that relative wealth holdings are unimportant conditional on total economic resources. Economic resources, no matter their source, reduce financial strain and contribute to relationship stability. The risk of divorce is higher among lowincome couples than among their higher-earning counterparts (Brines \& Joyner, 1999; Dechter, 1992 but see Heckert et al., 1998; Schoen et al., 2002; Tzeng \& Mare, 1995). Ono (1998) found that wives' earnings contribute to relationship stability, particularly when husbands' earnings are low. Regarding debt, previous research has linked total levels of debt to marital strain (Conger et al., 1999), which in turn increases the risk of divorce.

\section{Cohabiting Couples}

Cohabiting couples differ from married couples in ways that may shape their responses to asymmetric wealth accumulation. Several studies have shown that people who cohabit have less traditional relationship values, are less religious, and are more individualistic (Lesthaeghe \& Surkuyn, 1988; Rindfuss \& Van den Heuvel, 1990; Thomson \& Colella, 1992; Waite, 1995). In addition, attitudes toward gender roles are considerably more egalitarian among cohabitors 
(Blumstein \& Schwartz, 1983; Clarkberg, Stolzenberg, \& Waite, 1995; Smock, 2000). The economic theories of relationship stability discussed above were developed and tested mostly in the context of marriage. However, a few studies have tested how they operate in the context of cohabitation and found that similarity between partners is more stabilizing for cohabiting couples compared to married couples (Brines \& Joyner, 1999; Kalmijn et al., 2007).

\section{THE PRESENT STUDY}

Our study tests the implications of the gender norms, economic independence, and financial strain perspectives for homophily on wealth and debt. We examine how homophily, femaledominance, and male-dominance in asset and debt holdings shape relationship stability. We first untangle the different components of net worth and present a detailed picture of how holdings are distributed among married and cohabiting partners. We then test whether couples' asymmetry increases the risk of relationship dissolution and interpret the results in light of the three perspectives. Finally, we examine whether wealth and debt homophily exert different influences on the stability of marriages versus cohabitations.

\section{Data and Methods}

We use data from the 1996 to 2008 panels of the Survey of Income and Program Participation (SIPP), which span the years 1996 through 2013. The SIPP is a series of nationallyrepresentative panels, each lasting three to four years. Interviews occurred every four months and covered the previous four months. All household members aged 15 and older were interviewed directly if possible or by proxy from another household member otherwise. The SIPP imputes item and person nonresponse (Westat, 2001, Chapter 4: 4-1 - 4-17). A household roster indicates the relationship of each household member to the household head and monthly changes in the 
household roster are assessed at each survey. The SIPP follows all original sample members regardless of where they move in subsequent waves (unless they are institutionalized, in military barracks, or abroad). The SIPP also surveys new individuals who live with original members. In addition to regular core survey questions, the SIPP includes separate topical modules asked during two or three waves of each panel, one of which asks about assets and debts. See Supplementary Table 1 for information on topical modules and variables.

We construct an analytic subsample of families by identifying the household reference person, who we follow throughout the survey. We restrict the sample to working-age adults, 18 to 64 years old and opposite-sex couples. This results in a sample of 1,593,541 married familymonth observations (63,833 distinct relationships) and 114,812 cohabiting family-month observations (7,266 distinct relationships). We observe about $8 \%$ of married couples and about $30 \%$ of cohabiting couples end their unions during a SIPP panel.

\section{Measures}

Family structure and dissolution. In each month, we assess family structure by identifying households with a spouse present as married couples and households with an unmarried partner of the household head as cohabiting couples. We identify a marital dissolution as occurring in the month in which the household reference person's spouse is no longer present in the household, indicating either a separation or a legal divorce. We identify cohabitation dissolution as occurring in the month in which the cohabiting partner is no longer present. Cohabiting couples that marry exit the cohabiting sample and enter the married sample.

Family wealth and debt. We create four measures of wealth/debt derived from Czajka, Jacobson, \& Cody (2003) (see Supplementary Table 1). First, we calculate the value of all secured debt, which is mostly mortgages. Some have business debts secured by the value of the 
business. Second, unsecured debt is largely store and credit card debt. Third, liquid assets include savings and checking account balances. Fourth, illiquid assets include the values of participants' car(s) and their house or business. Information is collected on assets and debts held individually, as well as some jointly-held by spouses. In the case of automobiles, homes, and businesses, participants indicate what percent of the equity is theirs and we attribute the value accordingly. We assume that any debt held on these assets is distributed in equal proportion to participants' equity stakes. We divide other jointly held assets or debts equally among partners. Values are adjusted to 2013 dollars using the Bureau of Labor Statistics CPI-U inflation adjustments.

We use information on each partners' assets and debts to construct two measures of homophily. For a continuous measure, we calculate the difference between the male partner's holdings and the female partner's and normalize by the total value of both partners' holdings: (male holdings - female holdings) / total holdings. Figure 1 shows the distributions of these continuous measures. The $\mathrm{x}$-axis indicates the degree of homophily on a scale from -1 (female partner holds all assets or debts) to 1 (male partner holds all assets or debts). The middle, at 0 , indicates equal holdings of assets and debts.

[Figure 1]

This figure reveals several differences between married and cohabiting couples' holdings. First, married couples tend to be more equal in their holdings of all types of assets and debts compared to cohabiting couples, which is reflected in the large spike around 0. Second, a larger share of cohabiting couples are female-dominant on asset holdings. Although the patterns of wealth holdings look similar for stable and unstable cohabiting unions, the patterns of wealth 
holdings diverge for stable and unstable marriages. In particular, a larger share of male-dominant couples appear in the stable marriage group compared to the unstable marriage group.

We take the absolute value of this normalized difference to assess whether the extent of heterophily matters. However, this measure does not allow us to analyze whether the gender of the partner with greater holdings matters. Nor does it allow us to distinguish between those who are homophilous with some holdings from those who simply have no assets or debts. To address these limitations, we also construct categorical measures that separate female-dominant, maledominant, and couples with zero holdings from homophilous couples. If neither partner holds a third less than the other, we consider them to be homophilous. Couples with a normalized difference from -0.2 to 0.2 are coded as homophilous. A normalized difference of -1.0 to -0.2 is coded as female-dominant, and differences of 0.2 or greater are coded as male-dominant. We tested the results for robustness around this cutoff by estimating models using a .11 cutoff and a .33 cutoff, with substantively similar results (available upon request).

Race, ethnicity, and education. We use the race and ethnicity of the reference person and maintain four categories: non-Hispanic white, non-Hispanic black, Hispanic, and non-Hispanic other race. We record years of education completed for the reference person into four categories: less than high school (<12 years), high school (12 years), some college (13-15 years), and fouryear degree or higher $(16 \leq$ years $)$. Table 2 shows the distribution of household heads by raceethnicity and education.

Time-varying covariates. Total family net worth is measured as total family assets, less total family debts. Total monthly family income is measured in each month by calculating the sum of the total person income measures for the reference person and his or her spouse or partner. We include relative income, measured as the female partners' proportion of total income (i.e., female 
income / total income). We lag this measure by one month. Age is included as the reference person's age in years. We include a dichotomous variable indicating whether there are children as part of the SIPP-defined family (whether they are the respondent's biological children or not). We also include a four-category measure of couples' employment in the previous month: only male partner employed, only female partner employed, both employed, or neither employed. Net worth, income, and the continuous measures of asset and debt homophily have been standardized to ease interpretation of the coefficients.

\section{Method}

Our analyses use event-history models of time to union dissolution. We use Cox proportional hazards models to estimate the risk of dissolution as a function of wealth and debt homophily and other family characteristics. Respondents who enter the survey period already in a marriage or cohabiting relationship are immediately in the risk set. Respondents who enter unions during the course of the panel enter the risk set the first time the union is recorded. To test the results for robustness to the left censoring of respondents already in a union at the start of the panel, we estimate our models on a sub-sample of married respondents for whom we have full relationship duration information from a topical module. Results for this sub-sample do not vary substantively from the full sample results presented below and are presented in Supplementary Table 2. We measure time as months since union entry (or since the survey began for those already in a union), and participants are censored at the end of the survey period (or, for cohabitors, if they get married). We allow respondents to contribute multiple dissolutions and adjust for this dependence with robust standard errors. Thus, our unit of analysis is the relationship-month. 
Because we conduct a monthly survival analysis, but our key asset and debt independent variables are measured only every 12 months in the topical modules, we forward-fill the asset and debt values between topical modules. For example, if a couple responds to the topical module in wave three, and again in wave nine, we fill in the wave three values for waves four through eight. This assumes that asset and debt values do not change between waves; linear interpolation would be problematic because couples end their unions between waves of the topical modules. Because wealth is a stock rather than a flow, it is more stable from period to period and thus filling is less of a concern than for more volatile economic characteristics.

\section{RESULTS}

\section{Wealth}

Model 1 in Table 3 is a baseline model that includes net worth, income, female partner income proportion, and employment, as well as the controls. For each standard deviation increase in net worth, a couple's risk of dissolution decreases by $29 \%$. Income also has a stabilizing effect, but female income share is destabilizing: for each additional percent of the family income earned by the female partner in the previous month, the risk of dissolution increases by $30 \%$. Both partners being employed in the previous month compared to neither partner decreases the dissolution risk by $30 \%$. If only the male partner was employed, compared to neither partner, the risk decreases by $34 \%$. If only the female partner was employed, compared to neither partner, the risk decreases by $17 \%$. Consistent with prior literature, older age, children, and more education are associated with less risk of dissolution. Finally, all else equal, cohabiting relationships are less stable than marriages: cohabiting couples are 3.19 times more likely to dissolve their unions than married couples. 


\section{[Table 3]}

Model 2 adds the continuous homophily measures, which range from zero (equal holdings for each partner) to one (one partner holds all assets). This model shows that greater heterophily on either liquid or illiquid assets increases the risk of dissolution. For each additional standard deviation increase toward heterophilous holdings of liquid assets, the risk of dissolution increases by $6 \%$. For each standard deviation increase toward heterophily for illiquid assets, the risk of dissolution increases by $22 \%$.

In Model 3, we replace the continuous measures of homophily with the categorical measures. This allows for an assessment of the relative hazard for male- and female-dominant couples as well as for couples in which neither partner has any holdings. The results for assets in Model 3 indicate strong support for the economic independence perspective and weaker support for the gender norms perspective. First, both female- and male-dominant couples are at an increased risk of dissolution compared to homophilous couples with asset holdings (the reference category), net of total net worth, household income, female income proportion, employment, and other demographic controls. For liquid assets, female-dominant couples are at a 32\% increased risk of dissolution compared to homophilous couples, while male-dominant couples are at an $20 \%$ increased risk. Similarly, for illiquid assets, female-dominant couples are at a $51 \%$ increased risk of dissolution compared to homophilous couples, while male-dominant couples are at a $29 \%$ increased risk. These results are displayed graphically in Figure 2.

[Figure 2] 
The variation in effect size between male-dominant and female-dominant couples is statistically significant, indicated by the x-shaped points for the female-dominant couples in Figure 2. This also provides some support the gender norms perspective. Finally, these results indicate little support for the financial strain perspective, as partner dominance matters for relationship stability net of total resources.

Debt

We now discuss the results from Table 3 for secured and unsecured debt. Returning to Model 2, as with assets, greater heterophily in unsecured debt increases the risk of dissolution: for each standard deviation increase toward heterophilous holdings of unsecured debt, the risk of dissolution increases by $16 \%$. If the female partner holds more (Model 3), the risk of dissolution increases by $47 \%$. If the male partner holds more, the risk increases by $46 \%$ as well. These results are consistent with our predictions from the economic independence perspective: heterophily, no matter the gender, is destabilizing.

Secured debt is the exception to the general pattern: the risk of dissolution decreases by $5 \%$ for each standard deviation increase toward heterophilous secured debt holdings (Model 2) and neither female nor male-dominant couples are statistically different from homophilous couples (Model 3). Additionally, couples with no secured debt have a significantly greater risk of dissolution $(28 \%)$ than homophilous couples with secured debt. The results for secured debt go against our predictions from all three perspectives (see Table 1), an anomaly we consider in the discussion.

Relationship Type 
We estimate Model 3 separately for married and cohabiting couples and find that homophilous asset and debt holdings influence relationship stability differently by union type. Table 4 (and Figure 2 in the cohabiting and married panels) shows that married couples reflect a similar but more extreme pattern as the full sample, with stronger evidence for the gender norms perspective. For both types of assets, the increased risk of dissolution is at least twice as large for female-dominant couples as for male-dominant couples. These gender differences are statistically significant. Further, for married couples, female asset-dominant couples have a similar risk of dissolution as married couples with no assets. Among cohabiting couples, the results do not support the gender norms perspective. The point estimates for the risk of dissolution for male- and female-dominant couples on liquid and illiquid assets are either just above or just below the $\mathrm{p}<.05$ threshold for significance. Further, the point estimates for maleand female-dominant couples are not significantly different from each other, unlike for married couples.

[Table 4]

Married and cohabiting couples show different patterns for debt as well. Unsecured debt heterophily is highly consequential for married couples but not at all for cohabiting couples, while the reverse is true for secure debt. Among married couples, secured debt is the only measure on which heterophily is not associated with instability - neither male- nor femaledominant married couples are at an increased risk of dissolution from homophilous couples. For cohabiting couples, secured debt is the only measure on which heterophily, whether male- or female-dominant, does significantly increase the risk of dissolution. We considered whether 
differential age compositions may be driving differences between married and cohabiting couples. We re-estimated Model 3 for household heads age 40 or younger and the results are similar to those for the unrestricted samples (see Supplementary Table 3).

\section{DISCUSSION}

Assortative mating along economic dimensions has been increasing during several decades of growing wealth inequality (Dahan \& Gaviria, 2001; Fernández et al., 2005; Han, 2010; Heaton \& Mitchell, 2012; Mare, 1991; Schwartz, 2013; Torche, 2010). In this study, we examine the consequences of this economic similarity for relationship stability. Specifically, we test how partners' relative wealth and debt accumulation - two understudied economic factors in family scholarship — shape the risk of dissolution, above and beyond more standard economic measures such as net worth, income, relative income, and employment. In general, we find that wealth homophilous couples are the most stable. This could compound growing economic stratification as it suggests that assortative mating among couples with wealth generates inequality not only in family formation but also in relationship stability (McLanahan, 2004; Schwartz, 2010; Tach \& Eads, 2016).

Our finding that wealth homophilous couples are generally the most stable is most consistent with the economic independence perspective. Homophily in illiquid assets, in particular, seems to be an important protective factor for coresidential relationships. We find little support for the traditional gender norms perspective, by contrast: in no case were male-dominant wealth or debt holdings more stable than equal holdings. We do find evidence for a weaker version of the gender norms perspective for asset holdings, however. Although both male- and femaledominant couples were both less stable than homophilous couples, female-dominant couples 
were also significantly less stable than male-dominant couples, net of total net worth and other economic characteristics. This result is consistent with other literature that finds nontraditional specialization — women out-earning their husbands — has a destabilizing effect (Bertrand et al., 2015; Brines \& Joyner, 1999; Kalmijn, Loeve, \& Manting, 2007; Killewald, 2016). We find little support for the financial strain perspective - that relative asset holdings do not matter net of total holdings - in any of our asset models.

The wealth patterns discussed above hold true only for married couples, however. Neither economic independence nor nontraditional specialization in assets are destabilizing for cohabiting couples, among whom wealth heterophilous couples are not consistently different than wealth homophilous couples. Female-dominant cohabiting couples also do not face a different risk of dissolution than male-dominant couples. The divergent findings for cohabiters highlights the distinctive nature of cohabitation and marriage as family institutions.

Our analyses reveal two notable and divergent patterns for debt homophily relative to asset homophily, showing that assets and debt are indeed not "two sides of the same coin" (Dew, 2007, p. 1). First, secured debt is stabilizing for couples (Addo \& Sassler, 2010; Treas, 1993), perhaps serving as a marker for, and reinforcing, more committed relationships. For married couples, male- or female- dominance on secured debt does not predict greater instability, a marked divergence from the other findings for married couples. Second, for cohabiting couples, secured debt heterophily is associated with greater instability - and male- or female- dominance on secured debt is about as destabilizing as having no secured debt at all. These distinctive patterns by debt type and union type may be caused by the unique legal rights and obligations of marriage- in many states, debt accrued during the marriage is considered community property and divided equally in the event of a divorce. Future research might explore whether the results 
found here vary across states depending on the legal statutes regarding the treatment of debt in divorce.

The results of this study have broad implications for family scholarship on assortative mating and relationship stability. Our findings make a strong case for the important and distinctive role that wealth and debt play in shaping relationship dynamics above and beyond the more common economic measures family scholars typically use like income or employment. Additionally, we highlight not just the contours of assortative mating on wealth but also its consequences for relationship stability. Our results suggest that it may be more accurate to say that, in fact, "[s]imilarity breeds connection" and stability (McPherson et al., 2001, p. 415). Yet growing assortative mating on wealth in contexts of high inequality contributes not only to growing wealth inequality in partnering and family formation, but also in relationship stability: the current high inequality regime in the U.S. may facilitate more stable relationships for the most advantaged couples in which both partners hold wealth, but undermine relationship stability among less advantaged couples, compounding economic stratification. 


\section{REFERENCES}

Addo, F. R. \& Sassler, S. (2010). Financial arrangements and relationship quality in low-income couples. Family Relations, 59(4), 408-423. doi:10.1111/j.1741-3729.2010.00612.x.

Amato, P. R. \& Rogers, S. J. (1997). A longitudinal study of marital problems and subsequent divorce. Journal of Marriage and the Family, 59(3), 612-624. doi:10.2307/353949.

Baek, E. \& Hong, G. (2004). Effects of family life-cycle stages on consumer debts. Journal of Family and Economic Issues, 25(3), 359-385. doi:10.1023/B:JEEI.0000039946.59422.5f.

Becker, G. S. (1974). A theory of marriage: Part II. Journal of Political Economy, 82(2, Part 2), $11-26$.

Becker, G. S. (1981). A treatise on the family. Cambridge: Harvard University Press.

Bertrand, M., Kamenica, E. \& Pan J. (2015). Gender identity and relative income within households. The Quarterly Journal of Economics, 130(2), 571-614. doi:10.1093/qje/qjv001.

Blackwell, D. L. (1998). Marital homogamy in the united states: The influence of individual and paternal education. Social Science Research, 27(2),159-188. doi:10.1006/ssre.1998.0618.

Blackwell, D. L. \& Lichter, D. T. (2004). Homogamy among dating, cohabiting, and married couples. The Sociological Quarterly, 45(4), 719-737. doi:10.1111/j.15338525.2004.tb02311.x.

Blumstein, P. \& Schwartz, P. (1983). American couples: Money, work, sex. New York: William Morrow.

Bratter, J. L. \& King, R. B. (2008). ‘But will it last?’: Marital instability among interracial and same-race couples. Family Relations, 57(2), 160-171. doi: 10.1111/j.17413729.2008.00491.x.

Brines, J. \& Joyner, K. (1999). The ties that bind: Principles of cohesion in cohabitation and Eads, Griffin, and Tach 19 
marriage. American Sociological Review, 64(3), 333-355. doi: 10.2307/2657490.

Britt, S., Grable, J. E., Nelson Goff, B. S. \& White, M. (2008). The influence of perceived spending behaviors on relationship satisfaction. Journal of Financial Counseling and Planning, 19(1), 31-43.

Charles, K. K., Hurst, E. \& Killewald, A. (2013). Marital sorting and parental wealth. Demography, 50(1), 51-70. doi:10.1007/s13524-012-0144-6.

Cherlin, A. (1979). Work life and marital dissolution. In Levinger, G. and Moles, O.C. (eds.), Divorce and separation: Context, causes and consequences. New York: Basic Books.

Clarkberg, M., Stolzenberg R. M., \& Waite, L. J. (1995). Attitudes, values, and entrance into cohabitational versus marital unions. Social Forces, 72(2), 609-632. doi:10.1093/sf/74.2.609.

Conger, R. D., \& Elder Jr., G. H. (1994). Families in troubled times: Adapting to change in rural America. Social Institutions and Social Change.

Conger, R. D., Rueter, M.A., \& Elder Jr., G. H. (1999). Couple resilience to economic pressure. Journal of Personality and Social Psychology, 76(1), 54-71.

Czajka, J. L., Jacobson, J. E. \& Cody, S. (2003). Survey estimates of wealth: A comparative analysis and review of the Survey of Income and Program Participation. Social Security Bulletin, 65(1), 63.

Dahan, M., \& Gaviria, A. (2001). Sibling correlations and intergenerational mobility in Latin America. Economic Development and Cultural Change, 49(3), 537-554. doi:10.1086/452514.

Dechter, R. (1992). Constraint Networks. Information and Computer Science, University of Eads, Griffin, and Tach 20 
California, Irvine.

Dew, J. (2007). Two sides of the same coin? The differing roles of assets and consumer debt in marriage. Journal of Family and Economic Issues, 28(1), 89-104. doi:10.1007/s10834-0069051-6.

Drentea, P. (2000). Age, debt and anxiety. Journal of Health and Social Behavior, 41(4), 437-450. doi: 10.2307/2676296.

Eads, A. \& Tach, L. (2016). Wealth and inequality in the stability of romantic relationships. The Russell Sage Foundation Journal of the Social Sciences, 2(6), 197-224. doi:10.7758/RSF.2016.2.6.10.

Fisher, J., Johnson, D., Latner, J. P., Smeeding, T., and Thompson, J. (2016). Inequality and mobility using income, consumption, and wealth for the same individuals. RSF: The Russell Sage Foundation Journal of the Social Sciences, 2(6), 44-58. doi:10.7758/RSF.2016.2.6.03.

Fernández, R., Guner, N., \& Knowles, J. (2005). Love and money: A theoretical and empirical analysis of household sorting and inequality. The Quarterly Journal of Economics, 120(1), 273-344. doi:10.1162/0033553053327498.

Gerson, K. (2009). The unfinished revolution: Coming of age in a new era of gender, work, and family. Oxford University Press.

Han, H. (2010). Trends in educational assortative marriage in China from 1970 to 2000. Demographic Research, 22(24), 733-770. doi:10.4054/DemRes.2010.22.24.

Heaton, T. B. (2002). Factors contributing to increasing marital stability in the United States. Journal of Family Issues, 23(3), 392-409. doi:10.1177/0192513X02023003004.

Heaton, T. B. \& Mitchell, C. (2012). Changing intergroup boundaries in Brazilian marriages: 1991-2008. Journal of Comparative Family Studies, 43, 461-482. 
Heckert, D. A., Nowak, T.C., \& Snyder, K. A. (1998). The impact of husbands' and wives' relative earnings on marital disruption. Journal of Marriage and the Family, 60(3), 690703. doi:10.2307/353538.

Jalovaara, M. (2003). The joint effects of marriage partners' socioeconomic positions on the risk of divorce. Demography, 40(1), 67-81. doi:10.1353/dem.2003.0004.

Joyner, K. \& Kao, G. (2005). Interracial relationships and the transition to adulthood. American Sociological Review, 70(4), 563-581. doi:10.1177/000312240507000402.

Kalmijn, M. (1991). Shifting Boundaries: Trends in religious and educational homogamy. American Sociological Review, 56(6), 786-800. doi:10.2307/2096256.

Kalmijn, M., de Graaf, P. M., \& Janssen, J. P. G. (2005). Intermarriage and the risk of divorce in the Netherlands: The effects of differences in religion and in nationality, 1974-94. Population Studies, 59(1), 71-85. doi:10.1080/0032472052000332719.

Kalmijn, M., Loeve, A., \& Manting, D. (2007). Income dynamics in couples and the dissolution of marriage and cohabitation. Demography, 44(1), 159-179. doi:10.1353/dem.2007.0005.

Keister, L. A. (2000). Wealth in America: Trends in wealth inequality. Cambridge University Press.

Keister, L. A. \& Moller, S. (2000). Wealth inequality in the United States. Annual Review of Sociology, 26(1), 63-81. doi: 10.1146/annurev.soc.26.1.63.

Killewald, A. (2013). A reconsideration of the fatherhood premium: Marriage, coresidence, biology, and fathers' wages. American Sociological Review, 78(1), 96-116. doi:10.1177/0003122412469204.

Killewald, A. (2016). Money, work, and marital stability: Assessing change in the gendered 
determinants of divorce. American Sociological Review, 81(4), 696-719.

doi:10.1177/0003122416655340.

Lesthaeghe, R. \& Surkuyn, J. (1988). Cultural dynamics and economic theories of fertility change. Population and Development Review, 14, 1-45. doi:10.2307/1972499.

Mare, R. D. (1991). Five decades of educational assortative mating. American Sociological Review, 56(1), 15-32. doi:10.2307/2095670.

McLanahan, S. (2004). Diverging destinies: How children are faring under the second demographic transition. Demography, 41(4), 607-627. doi:10.1353/dem.2004.0033.

McPherson, M., Smith-Lovin, L., \& Cook, J. M. (2001). Birds of a feather: Homophily in social networks. Annual Review of Sociology, 27(1), 415-444. doi:10.1146/annurev.soc.27.1.415.

Oliver, M. L. \& Shapiro, T. M. (1995). Black wealth, white wealth: A new perspective on racial inequality. New York: Routledge.

Ono, H. (1998). Husbands' and wives' resources and marital dissolution. Journal of Marriage and the Family, 60(3), 674-689. doi:10.2307/353537.

Oppenheimer, V. K. (1997). Women's employment and the gain to marriage: The specialization and trading model. Annual Review of Sociology, 23(1), 431-453. doi:10.1146/annurev.soc.23.1.431.

Parsons, T. (1949). The system of modern societies. Englewood Cliffs, NJ: Prentice-Hall.

Pedulla, D. S. \& Thébaud, S. (2015). Can we finish the revolution? Gender, work-family ideals, and institutional constraint. American Sociological Review, 80(1), 116-139. doi:10.1177/0003122414564008.

Rauscher, E. (2016). Passing it on: Parent-to-adult child financial transfers for school and socioeconomic attainment. The Russell Sage Foundation Journal of the Social 
Sciences, 2(6), 172-196. doi:10.7758/RSF.2016.2.6.09.

Rindfuss, R. R., \& VandenHeuvel, A. (1990). Cohabitation: A precursor to marriage or an alternative to being single? Population and Development Review, 16(4), 703-726. doi:10.2307/1972963.

Rogers, S. J. (2004). Dollars, dependency, and divorce: Four perspectives on the role of wives' income. Journal of Marriage and Family, 66(1), 59-74. doi: 10.1111/j.17413737.2004.00005.x.

Ruggles, S. (1997). The rise of divorce and separation in the United States, 1880-1990. Demography, 34(4), 455-466. doi:10.2307/3038300.

Sayer, L. \& Bianchi, S. M. (2000). Women's economic independence and the probability of divorce: A review and reexamination. Journal of Family Issues, 21(7), 906-943. doi:10.1177/019251300021007005.

Sayer, L.C., England, P., Allison, P. D., and Kangas, N. (2011). She left, he left: How employment and satisfaction affect women's and men's decisions to leave marriages. American Journal of Sociology, 116(6), 1982-2018. doi:10.1086/658173.

Schneider, D. (2011). Market earnings and household work: New tests of gender performance theory. Journal of Marriage and Family, 73(4), 845-860. doi:10.1111/j.17413737.2011.00851.x.

Schoen, R., Astone, N. M., Kim, Y. J., Rothert, K., \& Standish, N. J. (2002). Women's employment, marital happiness, and divorce. Social Forces, 81(2), 643-662. doi:10.1353/sof.2003.0019.

Schoen, R. \& Wooldredge, J. (1989). Marriage choices in North Carolina and Virginia, 1969-71 and 1979-81. Journal of Marriage and the Family, 51(2), 465-481. doi:10.2307/352508. 
Schwartz, C. R. (2010). Pathways to educational homogamy in marital and cohabiting unions. Demography, 47(3), 735-753. doi:10.1353/dem.0.0124.

Schwartz, C. R. (2013). Trends and variation in assortative mating: Causes and consequences. Annual Review of Sociology, 39(1), 451-470. doi:10.1146/annurev-soc-071312-145544.

Smock, P. J. (2000). Cohabitation in the United States: An appraisal of research themes, findings, and implications. Annual Review of Sociology 26, 1-20. doi:10.1146/annurev.soc.26.1.1.

South, S. J. (2001). Time-dependent effects of wives' employment on marital dissolution. American Sociological Review, 66(2), 226-245. doi: 10.2307/2657416.

Spanier, B., \& Glick, P. C. (1980). Mate selection differentials between whites and blacks in the United States. Social Forces, 58(3), 707-725. doi: 10.1093/sf/58.3.707.

Teachman, J. (2010). Wives' economic resources and risk of divorce. Journal of Family Issues, 31(10), 1305-23. doi:10.1177/0192513X10370108.

Thomson, E., \& Colella, U. (1992). Cohabitation and marital stability: Quality or commitment? Journal of Marriage and the Family, 54(2), 259-267. doi:10.2307/353057.

Torche, F. (2010). Educational assortative mating and economic inequality: A comparative analysis of three Latin American countries. Demography, 47(2), 481-502. doi:10.1353/dem.0.0109.

Townsend, N. (2010). Package deal: Marriage, work and fatherhood in men's lives. Temple University Press.

Treas, J. (1993). Money in the bank: Transaction costs and the economic organization of marriage. American Sociological Review, 58(5), 723-734. doi:10.2307/2096283.

Tzeng, J. M. \& R. D. Mare. (1995). Labor market and socioeconomic effects on marital stability. Eads, Griffin, and Tach 25 
Social Science Research, 24(4), 329-351. doi:10.1006/ssre.1995.1013.

Tzeng, M. (1992). The effects of socioeconomic heterogamy and changes on marital dissolution for first marriages. Journal of Marriage and the Family, 54(3), 609-619. doi:10.2307/353246.

Waite, L. J. (1995). Does marriage matter? Demography, 32(4), 483-507. doi:10.2307\%2F2061670.

Westat. (2001). Survey of income and program participation users' guide: Supplement to the technical documentation. Third edition. Washington, D.C.

Zhang, Y. \& Van Hook, J. (2009). Marital dissolution among interracial couples. Journal of Marriage and Family, 71(1), 95-107. doi:10.1111/j.1741-3737.2008.00582.x. 
Table 1. Predictions from Three Perspectives Regarding Asymmetrical Accumulation of Wealth and Debt for Relationship Stability

\begin{tabular}{ccc}
\hline \multicolumn{1}{c}{ Gender Norms } & Economic Independence & Financial Strain \\
\hline \hline$\frac{\text { Wealth }}{\text { Male }}>$ Equal $>$ Female & $\frac{\text { Wealth }}{\text { Equal }>\text { Male }=\text { Female }}$ & $\frac{\text { Wealth }}{\text { Equal }=\text { Male }=\text { Female }}$ \\
$\frac{\text { Debt }}{\text { Male }>\text { Equal }>\text { Female }}$ & $\frac{\text { Debt }}{\text { Equal }>\text { Male }=\text { Female }}$ & $\frac{\text { Debt }}{\text { Equal }=\text { Male }=\text { Female }}$
\end{tabular}

Note: Couple types are arranged from most to least stable. Male means the male partner has greater holdings of wealth or debt. Female means the female partner does. Equal refers to homophilous couples. 
Table 2. Sample Descriptive Statistics

\begin{tabular}{|c|c|c|c|c|c|}
\hline & \multirow{2}{*}{$\begin{array}{c}\text { Full } \\
\text { Sample } \\
\end{array}$} & \multicolumn{2}{|c|}{ Married } & \multicolumn{2}{|c|}{ Cohabiting } \\
\hline & & $\begin{array}{c}\text { No } \\
\text { Dissolution }\end{array}$ & Dissolution & $\begin{array}{c}\text { No } \\
\text { Dissolution }\end{array}$ & Dissolution \\
\hline \multicolumn{6}{|l|}{ Homophily-Heterophily } \\
\hline Relative Secured Debt & $.12(.30)$ & $.10(.28)$ & $.14(.32)$ & $.33(.47)$ & $.32(.46)$ \\
\hline Relative Unsec. Debt & $.18(.34)$ & $.16(32)$ & $.23(.37)$ & $.45(.46)$ & $.48(.46)$ \\
\hline Relative Liquid Assets & $.44(.39)$ & $.43(.38)$ & $.46(.42)$ & $.55(.44)$ & $.57(.44)$ \\
\hline Relative Illiquid Assets & $.25(.36)$ & $.22(.33)$ & $.34(.41)$ & $.66(.41)$ & $.66(.41)$ \\
\hline Monthly Income ${ }^{a}$ & $\$ 73(\$ 67)$ & $\$ 75(\$ 68)$ & $\$ 58(\$ 52)$ & $\$ 54(\$ 49)$ & $\$ 49(\$ 42)$ \\
\hline Female Income Proportion & $.34(.28)$ & $.33(.28)$ & $.37(.30)$ & $.43(.29)$ & $.44(.31)$ \\
\hline Net Worth ${ }^{\mathrm{b}}$ & $\$ 27(\$ 127)$ & $\$ 29(\$ 134)$ & $\$ 14(\$ 28)$ & $\$ 11(\$ 28)$ & $\$ 8(\$ 26)$ \\
\hline Age & 44 & 45 & 41 & 39 & 37 \\
\hline \multicolumn{6}{|l|}{ Relationship Type } \\
\hline Cohabiting & $7 \%$ & - & - & $84 \%$ & $17 \%$ \\
\hline Married & $93 \%$ & $97 \%$ & $4 \%$ & - & - \\
\hline \multicolumn{6}{|l|}{ Employed } \\
\hline Both Partners & $62 \%$ & $62 \%$ & $58 \%$ & $60 \%$ & $58 \%$ \\
\hline Female Only & $8 \%$ & $7 \%$ & $10 \%$ & $11 \%$ & $12 \%$ \\
\hline Male Partner & $25 \%$ & $25 \%$ & $24 \%$ & $22 \%$ & $22 \%$ \\
\hline Neither Partner & $6 \%$ & $6 \%$ & $8 \%$ & $7 \%$ & $9 \%$ \\
\hline Households with Children & $55 \%$ & $56 \%$ & $61 \%$ & $42 \%$ & $41 \%$ \\
\hline \multicolumn{6}{|l|}{ Race/Ethnicity } \\
\hline Black & $7 \%$ & $7 \%$ & $10 \%$ & $11 \%$ & $12 \%$ \\
\hline Latino & $13 \%$ & $12 \%$ & $16 \%$ & $19 \%$ & $13 \%$ \\
\hline Other & $6 \%$ & $6 \%$ & $5 \%$ & $4 \%$ & $4 \%$ \\
\hline White & $74 \%$ & $75 \%$ & $68 \%$ & $65 \%$ & $71 \%$ \\
\hline \multicolumn{6}{|l|}{ Education } \\
\hline Less than HS & $10 \%$ & $9 \%$ & $13 \%$ & $16 \%$ & $14 \%$ \\
\hline High School & $25 \%$ & $24 \%$ & $29 \%$ & $31 \%$ & $33 \%$ \\
\hline Some College & $33 \%$ & $33 \%$ & $38 \%$ & $36 \%$ & $38 \%$ \\
\hline Four Years & $32 \%$ & $34 \%$ & $20 \%$ & $17 \%$ & $15 \%$ \\
\hline $\mathrm{N}$ of Relationships & 71,505 & 58,778 & 5,055 & 5,112 & 2,154 \\
\hline Relationship-months & $1,708,353$ & $1,532,365$ & 61,176 & 94,783 & 20,029 \\
\hline
\end{tabular}

${ }^{\mathrm{a}}$ Income in hundreds ${ }^{\mathrm{b}}$ Net worth in ten thousands

Note: Statistics weighted using national sampling weights. Monetary values reported in 2013 dollars. The percentages in each column are based on the relationship-month observation totals at the bottom of each column. 
Table 3

Cox Proportional Hazard Analysis for Variables Predicting Dissolution of Romantic Relationships

\begin{tabular}{|c|c|c|c|c|c|c|}
\hline & \multicolumn{2}{|c|}{ Model 1} & \multicolumn{2}{|l|}{ Model 2} & \multicolumn{2}{|c|}{ Model 3} \\
\hline & $\begin{array}{c}B \\
(\text { Haz. Ratio })\end{array}$ & $S E B$ & $\begin{array}{c}\text { B } \\
\text { (Haz. Ratio) }\end{array}$ & $S E B$ & $\begin{array}{c}\text { B } \\
\text { (Haz. Ratio) } \\
\end{array}$ & $S E B$ \\
\hline Relative Liquid Assets & & & $\begin{array}{l}0.055^{* * *} \\
(1.06)\end{array}$ & 0.014 & & \\
\hline Relative Illiquid Assets & & & $\begin{array}{l}0.196 * * * \\
(1.22)\end{array}$ & 0.016 & & \\
\hline Relative Secured Debt & & & $\begin{array}{l}-0.050 * * \\
(0.951)\end{array}$ & 0.015 & & \\
\hline Relative Unsecured Debt & & & $\begin{array}{l}0.148 * * * \\
(1.160)\end{array}$ & 0.014 & & \\
\hline Liquid Assets (Homophilous=0) & & & & & & \\
\hline Female-Dominant & & & & & $\begin{array}{l}0.275 * * * \\
(1.317)\end{array}$ & 0.043 \\
\hline Male-Dominant & & & & & $\begin{array}{l}0.182 * * * \\
(1.200)\end{array}$ & 0.040 \\
\hline No Holdings & & & & & $\begin{array}{l}0.341 * * * \\
(1.406)\end{array}$ & 0.048 \\
\hline Illiquid Assets (Homophilous $=0$ ) & & & & & & \\
\hline Female-Dominant & & & & & $\begin{array}{l}0.410 * * * \\
(1.507)\end{array}$ & 0.047 \\
\hline Male-Dominant & & & & & $\begin{array}{l}0.256 * * * \\
(1.292)\end{array}$ & 0.043 \\
\hline No Holdings & & & & & $\begin{array}{l}0.479 * * * \\
(1.614)\end{array}$ & 0.064 \\
\hline Unsecured Debt (Homophilous $=0$ ) & & & & & & \\
\hline Female-Dominant & & & & & $\begin{array}{l}0.382 * * * \\
(1.465)\end{array}$ & 0.042 \\
\hline Male-Dominant & & & & & $\begin{array}{l}0.375 * * * \\
(1.455)\end{array}$ & 0.043 \\
\hline No Holdings & & & & & $\begin{array}{l}0.055 \\
(1.057)\end{array}$ & 0.037 \\
\hline Secured Debt (Homophilous $=0$ ) & & & & & & \\
\hline Female-Dominant & & & & & $\begin{array}{l}0.115 \\
(1.121)\end{array}$ & 0.065 \\
\hline Male-Dominant & & & & & $\begin{array}{l}0.072 \\
(1.075)\end{array}$ & 0.057 \\
\hline No Holdings & & & & & $\begin{array}{l}0.245^{* * *} \\
(1.278)\end{array}$ & 0.041 \\
\hline Net Worth (sd) & $\begin{array}{l}-0.343 * * * \\
(0.710)\end{array}$ & 0.048 & $\begin{array}{l}-0.334 * * * \\
(0.716)\end{array}$ & 0.046 & $\begin{array}{l}-0.314 * * * \\
(0.731)\end{array}$ & 0.044 \\
\hline Income (sd) & $\begin{array}{l}-0.105^{* * * *} \\
(0.900)\end{array}$ & 0.023 & $\begin{array}{l}-0.086^{* * *} \\
(0.918)\end{array}$ & 0.022 & $\begin{array}{l}-0.056^{* *} \\
(0.946)\end{array}$ & 0.021 \\
\hline Female Income Proportion & $\begin{array}{l}0.263 * * * \\
(1.301)\end{array}$ & 0.061 & $\begin{array}{l}0.242 * * * \\
(1.274)\end{array}$ & 0.061 & $\begin{array}{l}0.167 * * \\
(1.182)\end{array}$ & 0.062 \\
\hline $\begin{array}{l}\text { Employment }(\text { Neither }=0) \\
\text { Both Partners }\end{array}$ & $\begin{array}{l}-0.357 * * * \\
(0.700)\end{array}$ & 0.052 & $\begin{array}{l}-0.390 * * * \\
(0.677)\end{array}$ & 0.052 & $\begin{array}{l}-0.260 * * * \\
(0.771)\end{array}$ & 0.053 \\
\hline
\end{tabular}


Only Male

Only Female

Race / Ethnicity

$($ Non-Hispanic White $=0)$

Black

Hispanic

Other

Education (Less than $\mathrm{HS}=0$ )

High School

Some College

Four Year Degree or More

Age in Years

Children Present $(\mathrm{No}=0)$

Cohabiting $($ Married $=0)$
$-0.421^{*}$
$(0.656)$

$-0.182 * *$

(0.834)

$0.241 * * *$

(1.273)

$-0.135^{* *}$

(0.874)

0.108

(1.114)

$-0.083$

(0.920)

$-0.119^{*}$

(0.888)

$-0.507 * * *$

(0.602)

$-0.034 * * *$

(0.967)

$-0.249 * * *$

(0.780)

$1.161 * * *$

(3.19)
0.06

$(0.628)$

$0.065-0.236^{* * *}$

(0.790)

$$
\begin{array}{ll}
0.044 & 0.216^{* * *} \\
& (1.241) \\
0.048 & -0.138^{* *} \\
& (0.871) \\
0.060 & 0.071 \\
& (1.074)
\end{array}
$$

$0.047 \quad-0.086$

(0.918)

$0.047-0.132 * *$

(0.876)

$0.056-0.497 * * *$

(0.608)

$0.002-0.032 * * *$

(0.969)

$0.031-0.223 * * *$

$(0.800)$

$0.0340 .892 * * *$

(2.440)
$0.060-0.370 * * *$

(0.691)

$0.065-0.147 *$

(0.863)

$\begin{array}{lll}0.044 & 0.113 * & 0.045 \\ & (1.120) & \\ 0.048 & -0.204 * * * & 0.048 \\ & (0.815) & \\ 0.060 & 0.035 & 0.060 \\ & (1.036) & \end{array}$

$0.047 \quad-0.028$

(0.972)

$0.047 \quad-0.050$

$(0.951)$

$0.056-0.399 * * * \quad 0.057$

$(0.671)$

$0.001-0.030$ *** 0.001

(0.970)

$0.030-0.206^{* * *}$

$(0.814)$

$0.038 \quad 0.808 * * * \quad 0.037$

(2.243)

$1,708,353$

0.047

0.048

0.031

Note: Robust standard errors.

$1,708,353$

$1,708,353$

$* * * p<0.001, * * p<0.01, * p<0.05$

Eads, Griffin, and Tach 30 
Table 4. Cox Proportional Hazard Analysis for Variables Predicting Dissolution Separately for Married and Cohabiting Couples

\begin{tabular}{|c|c|c|c|c|}
\hline & \multicolumn{2}{|c|}{ Cohabiting } & \multicolumn{2}{|c|}{ Married } \\
\hline & $\begin{array}{c}B \\
(\text { Haz. Ratio })\end{array}$ & $S E B$ & $\begin{array}{c}B \\
\text { (Haz. Ratio) }\end{array}$ & $S E B$ \\
\hline \multicolumn{5}{|c|}{ Liquid Assets (Homophilous=0) } \\
\hline Female-Dominant & $\begin{array}{l}0.204 \\
(1.226)\end{array}$ & 0.116 & $\begin{array}{l}0.288 * * * \\
(1.334)\end{array}$ & 0.047 \\
\hline Male-Dominant & $\begin{array}{l}0.229 * \\
(1.257)\end{array}$ & 0.115 & $\begin{array}{l}0.151^{* *} \\
(1.163)\end{array}$ & 0.044 \\
\hline No Holdings & $\begin{array}{l}0.269 * \\
(1.309)\end{array}$ & 0.122 & $\begin{array}{l}0.355 * * * \\
(1.426)\end{array}$ & 0.053 \\
\hline \multicolumn{5}{|c|}{ Illiquid Assets (Homophilous=0) } \\
\hline Female-Dominant & $\begin{array}{l}0.209 * \\
(1.232)\end{array}$ & 0.104 & $\begin{array}{l}0.446 * * * \\
(1.562)\end{array}$ & 0.054 \\
\hline Male-Dominant & $\begin{array}{l}0.120 \\
(1.127)\end{array}$ & 0.103 & $\begin{array}{l}0.224 * * * \\
(1.251)\end{array}$ & 0.048 \\
\hline No Holdings & $\begin{array}{l}0.327 * * \\
(1.387)\end{array}$ & 0.122 & $\begin{array}{l}0.511 * * * \\
(1.667)\end{array}$ & 0.079 \\
\hline \multicolumn{5}{|c|}{ Unsecured Debt (Homophilous $=0$ ) } \\
\hline Female-Dominant & $\begin{array}{l}-0.035 \\
(0.966)\end{array}$ & 0.125 & $\begin{array}{l}0.456 * * * \\
(1.578)\end{array}$ & 0.046 \\
\hline Male-Dominant & $\begin{array}{l}0.017 \\
(1.017)\end{array}$ & 0.128 & $\begin{array}{l}0.387 * * * \\
(1.473)\end{array}$ & 0.050 \\
\hline No Holdings & $\begin{array}{l}-0.158 \\
(0.854)\end{array}$ & 0.127 & $\begin{array}{l}0.031 \\
(1.031)\end{array}$ & 0.040 \\
\hline \multicolumn{5}{|c|}{ Secured Debt (Homophilous $=0$ ) } \\
\hline Female-Dominant & $\begin{array}{l}0.538 * * \\
(1.713)\end{array}$ & 0.172 & $\begin{array}{l}0.048 \\
(1.049)\end{array}$ & 0.080 \\
\hline Male-Dominant & $\begin{array}{l}0.549 * * \\
(1.732)\end{array}$ & 0.168 & $\begin{array}{l}-0.051 \\
(0.950)\end{array}$ & 0.069 \\
\hline No Holdings & $\begin{array}{l}0.649 * * * \\
(1.914)\end{array}$ & 0.156 & $\begin{array}{l}0.210^{* * * *} \\
(1.234)\end{array}$ & 0.044 \\
\hline Observations & 114,812 & & $1,593,541$ & \\
\hline
\end{tabular}

Note: Controls included in the model but not shown in table: net worth, income, relative income, employment, race/ethnicity, education, age, and children. Robust standard errors.

$* * * p<0.001, * * p<0.01, * p<0.05$ 


\section{Liquid Assets}

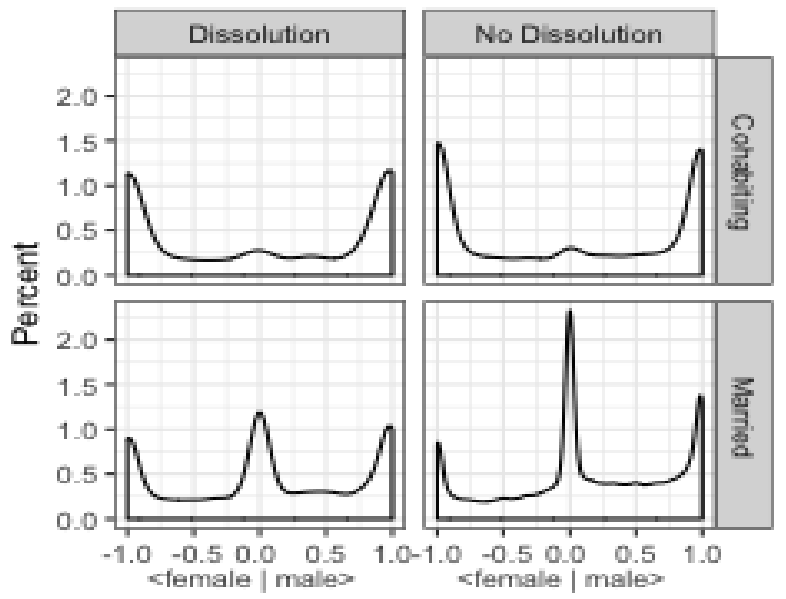

Secured Debt

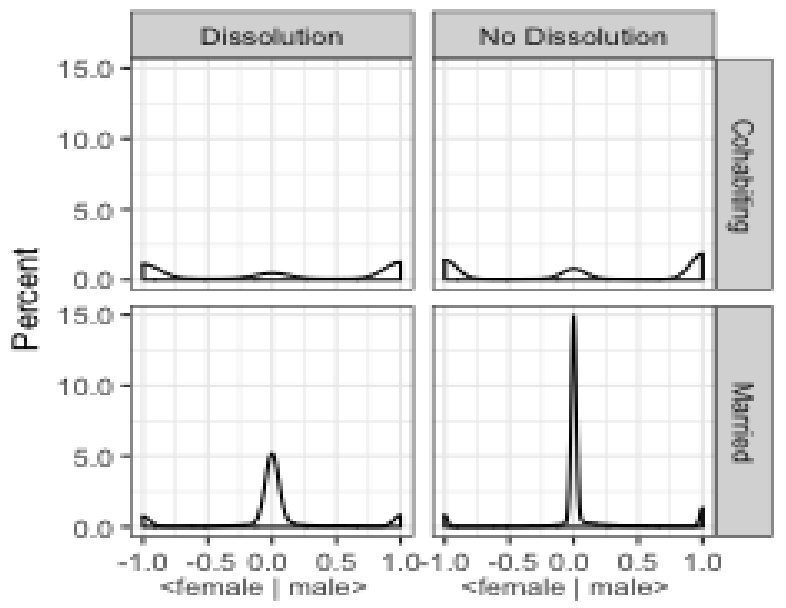

Illiquid Assets

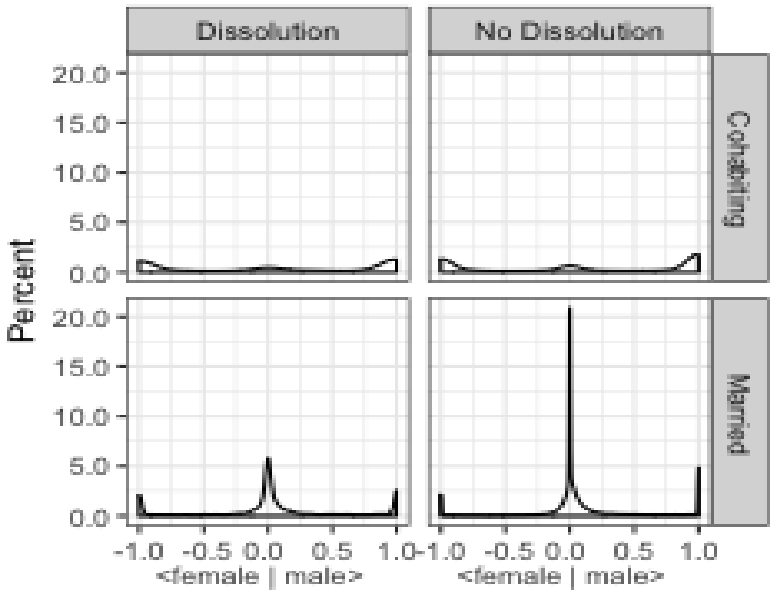

Unsecured Debt

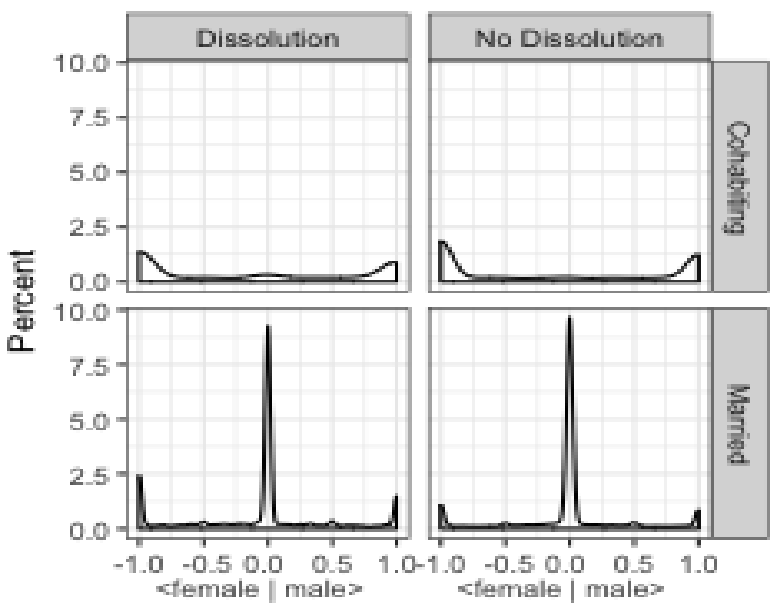

Note: Density plots show the distribution of completely female-dominant to homophilous to completely male-dominant couples on holdings of liquid and illiquid assets, secured and unsecured debt among married and cohabiting couples, as well by relationship stability. On the x-axis, -1 indicates a completely female-dominant couple, while 1 indicates a completely male-dominant couple. In the middle, 0 indicates couples with exactly equal holdings. The $\mathrm{y}$-axis shows the percent of couples at each location along the $\mathrm{x}$ axes. 
FIGURE 2. RELATIVE HAZARD COMPARED TO HOMOPHILOUS COUPLES FOR EACH OTHER COUPLE TYPE.

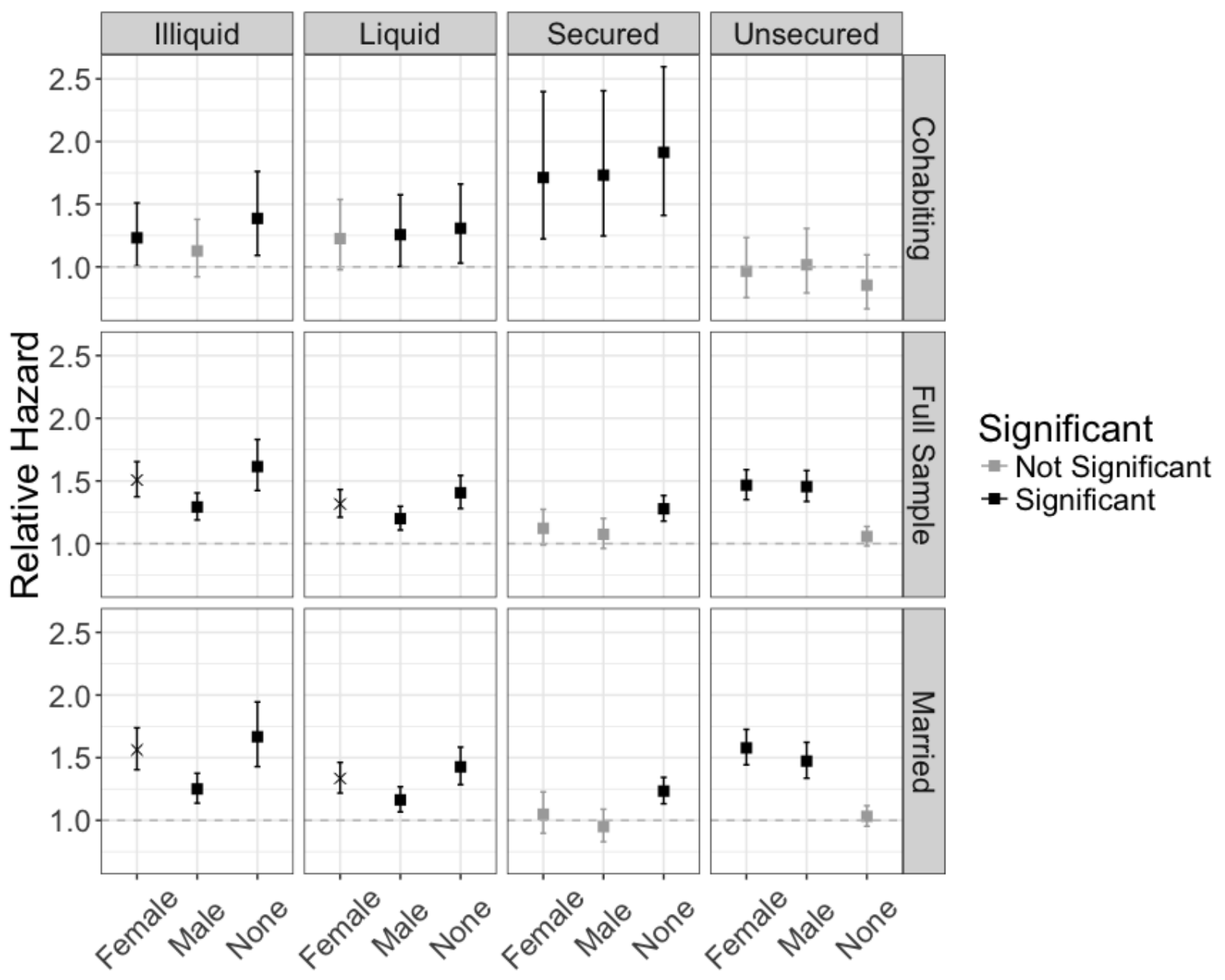

Note: Couple types are female-dominant (female), male-dominant (male), and couples with no holdings (none). The X-shaped point for female-dominant married and full sample couples indicates that the coefficient is significantly different $(p<0.05)$ than that for male-dominant couples. This figure graphs the results from Model 3 in Table 3 for the full sample panel; and the Cohabiting and Married models from Table 4 for the cohabiting and married panels, respectively. 
Supplementary Table 1. Content and variable names of SIPP assets and debt survey questions used in wealth / debt measures

\begin{tabular}{|c|c|c|}
\hline Measures & SIPP Variable Contents & SIPP Variable Name \\
\hline \multirow{6}{*}{$\begin{array}{l}\text { Unsecured } \\
\text { Debt }\end{array}$} & Credit card or store debt with partner & ealjdab or taljdab \\
\hline & $\begin{array}{l}\text { Credit card or store debt owed by reference } \\
\text { person }\end{array}$ & ealidab or talidab \\
\hline & Loans owed with partner & ealjdal or taljdal \\
\hline & Loans owed by reference person & ealidal or talidal \\
\hline & Other debt owed with partner & ealjdao or taljdao \\
\hline & Other owed by reference person & ealidao or talidao \\
\hline \multirow[t]{12}{*}{$\begin{array}{l}\text { Secured } \\
\text { Debt }\end{array}$} & $\begin{array}{l}\text { Debt on jointly held stocks or mutual } \\
\text { funds }\end{array}$ & esmjmav or tsmjmav \\
\hline & $\begin{array}{l}\text { Debt on reference person's stocks or } \\
\text { mutual funds }\end{array}$ & esmimav or tsmimav \\
\hline & Debt on mobile home or lot & tmhpr \\
\hline & Principle owed on mortgage & tmorlpr \\
\hline & & $\begin{array}{l}\text { (Could be more than one owner. Value } \\
\text { applied proportionally) }\end{array}$ \\
\hline & Principle owed on rental properties owned & trjpri \\
\hline & with partner & (Half value applied to both partners) \\
\hline & $\begin{array}{l}\text { Principle reference person owes on rental } \\
\text { properties }\end{array}$ & tripri \\
\hline & Auto loans & tcarval1, tcarval2, tcarval3 \\
\hline & & (Value applied proportionally to owners) \\
\hline & Business debt & tvbde 1, tvbde 2 \\
\hline & & (Value applied proportionally to owners) \\
\hline \multirow{8}{*}{$\begin{array}{l}\text { Liquid } \\
\text { Assets }\end{array}$} & Equity in investments & eoaeq (not asked in 2004 or 2008) \\
\hline & Amount in joint interest earning account & tiajta \\
\hline & $\begin{array}{l}\text { Amount in reference person interest earning } \\
\text { account }\end{array}$ & tiaita \\
\hline & Amount in joint checking account & taljcha \\
\hline & Amount in reference person checking account & talicha \\
\hline & Amount in joint bonds/US securities & timja \\
\hline & $\begin{array}{l}\text { Amount in reference person bonds/US } \\
\text { securities }\end{array}$ & timia \\
\hline & Value of joint stocks or mutual funds & esmjv or tsmjv \\
\hline
\end{tabular}




\begin{tabular}{|c|c|c|}
\hline & $\begin{array}{l}\text { Value of reference person stocks or mutual } \\
\text { funds }\end{array}$ & esmiv or tsmiv \\
\hline & Face Value of U.S. Savings Bonds & talsbv \\
\hline & Market value of IRA account(s) & talrb \\
\hline & Market value of KEOGH account(s) & talkb \\
\hline & Market value of $401 \mathrm{~K}$ & taltb \\
\hline \multirow[t]{11}{*}{$\begin{array}{l}\text { Illiquid } \\
\text { Assets }\end{array}$} & Value of house & $\begin{array}{l}\text { tpropval } \\
\text { (Applied proportionally) }\end{array}$ \\
\hline & Value of mobile home & tmhval \\
\hline & Value of other real estate & $\begin{array}{l}\text { tothreva } \\
\text { (Applied proportionally) }\end{array}$ \\
\hline & Value of $\operatorname{car}(\mathrm{s})$ & $\begin{array}{l}\text { carval1, carval2, carval3 } \\
\text { (Applied proportionally) }\end{array}$ \\
\hline & $\begin{array}{l}\text { Value of rental property jointly held not with } \\
\text { partner }\end{array}$ & trtsha \\
\hline & $\begin{array}{l}\text { Value of rental property jointly held with } \\
\text { partner }\end{array}$ & trjmv \\
\hline & $\begin{array}{l}\text { Value of rental property held by reference } \\
\text { person }\end{array}$ & trimv \\
\hline & Amount owed for sale business/property & ealowa or talowa \\
\hline & Principle owed on mortgage & tmip \\
\hline & Principle owed on mortgage jointly held & tmjp \\
\hline & Business equity & tvbva1, tvbva2 \\
\hline
\end{tabular}

Note: These variables are found in the topical modules included in waves 3, 6, 9, and 12 for the 1996 panel; 3, 6, and 9 for the 2001 panel; 3 and 6 for the 2004 panel; and 4, 7, and 10 for the 2008 panel. Some variable names change between panels. 
Supplementary Table 2. Cox Proportional Hazard Analysis for Variables Predicting Divorce

\begin{tabular}{|c|c|c|c|c|c|c|}
\hline & \multicolumn{2}{|c|}{ Model 1} & \multicolumn{2}{|c|}{ Model 2} & \multicolumn{2}{|c|}{ Model 3} \\
\hline & $\begin{array}{c}B \\
\text { (Haz. Ratio }\end{array}$ & $S E B$ & $\begin{array}{c}B \\
(\text { Haz. Ratio })\end{array}$ & $S E B$ & $\begin{array}{c}B \\
\text { (Haz. Ratio) }\end{array}$ & $S E B$ \\
\hline Relative Liquid Assets & & & $\begin{array}{l}0.033 \\
(1.034)\end{array}$ & 0.017 & & \\
\hline Relative Illiquid Assets & & & $\begin{array}{l}0.139 * * * \\
(1.149)\end{array}$ & 0.020 & & \\
\hline Relative Secured Debt & & & $\begin{array}{l}-0.076 * * * \\
(0.927)\end{array}$ & 0.020 & & \\
\hline Relative Unsecured Debt & & & $\begin{array}{l}0.136^{* * * *} \\
(1.146)\end{array}$ & 0.017 & & \\
\hline Liquid Assets (Homophilous=0) & & & & & & \\
\hline Female-Dominant & & & & & $\begin{array}{l}0.191 * * * \\
(1.210)\end{array}$ & 0.048 \\
\hline Male-Dominant & & & & & $\begin{array}{l}0.096^{*} \\
(1.101)\end{array}$ & 0.045 \\
\hline No Holdings & & & & & $\begin{array}{l}0.305 * * * \\
(1.357)\end{array}$ & 0.054 \\
\hline Illiquid Assets (Homophilous=0) & & & & & & \\
\hline Female-Dominant & & & & & $\begin{array}{l}0.298 * * * \\
(1.347)\end{array}$ & 0.056 \\
\hline Male-Dominant & & & & & $\begin{array}{l}0.108 * \\
(1.114)\end{array}$ & 0.050 \\
\hline No Holdings & & & & & $\begin{array}{l}0.386 * * * \\
(1.471)\end{array}$ & 0.080 \\
\hline Unsecured Debt (Homophilous=0) & & & & & & \\
\hline Female-Dominant & & & & & $\begin{array}{l}0.299 * * * \\
(1.349)\end{array}$ & 0.047 \\
\hline Male-Dominant & & & & & $\begin{array}{l}0.261 * * * \\
(1.298)\end{array}$ & 0.051 \\
\hline No Holdings & & & & & $\begin{array}{l}-0.036 \\
(0.965)\end{array}$ & 0.041 \\
\hline Secured Debt (Homophilous=0) & & & & & & \\
\hline Female-Dominant & & & & & $\begin{array}{l}-0.022 \\
(0.978)\end{array}$ & 0.082 \\
\hline Male-Dominant & & & & & $\begin{array}{l}-0.084 \\
(0.919)\end{array}$ & 0.072 \\
\hline No Holdings & & & & & $\begin{array}{l}0.143 * * \\
(1.154)\end{array}$ & 0.045 \\
\hline Net Worth (sd) & $\begin{array}{l}-0.278 * * * \\
(0.757)\end{array}$ & 0.045 & $\begin{array}{l}-0.265^{* * * *} \\
(0.767)\end{array}$ & 0.045 & $\begin{array}{l}-0.229 * * * \\
(0.795)\end{array}$ & 0.048 \\
\hline Income (sd) & $\begin{array}{l}-0.074 * * \\
(0.929)\end{array}$ & 0.025 & $\begin{array}{l}-0.062^{*} \\
(0.940)\end{array}$ & 0.024 & $\begin{array}{l}-0.046 \\
(0.955)\end{array}$ & 0.024 \\
\hline $\begin{array}{l}\text { Female Income Proportion } \\
\text { Employment (Neither=0) }\end{array}$ & $\begin{array}{l}0.294 * * * \\
(1.342)\end{array}$ & 0.073 & $\begin{array}{l}0.276^{* * * *} \\
(1.318)\end{array}$ & 0.073 & $\begin{array}{l}0.223 * * \\
(1.250)\end{array}$ & 0.074 \\
\hline Both Partners & $\begin{array}{l}-0.466 * * * \\
(0.628)\end{array}$ & 0.063 & $\begin{array}{l}-0.469 * * * \\
(0.626)\end{array}$ & 0.063 & $\begin{array}{l}-0.374 * * * \\
(0.688)\end{array}$ & 0.064 \\
\hline Only Male & $-0.540 * * *$ & 0.071 & $-0.555 * * *$ & 0.072 & $-0.479 * * *$ & 0.072 \\
\hline
\end{tabular}




\begin{tabular}{|c|c|c|c|c|c|c|}
\hline Only Female & $\begin{array}{l}(0.583) \\
-0.218^{* *} \\
(0.804)\end{array}$ & 0.079 & $\begin{array}{l}(0.574) \\
-0.234 * * \\
(0.791)\end{array}$ & 0.079 & $\begin{array}{l}(0.619) \\
-0.176^{*} \\
(0.839)\end{array}$ & 0.079 \\
\hline \multicolumn{7}{|l|}{ Race / Ethnicity } \\
\hline Black & $\begin{array}{l}0.180 * * \\
(1.197)\end{array}$ & 0.053 & $\begin{array}{l}0.137 * \\
(1.147)\end{array}$ & 0.053 & $\begin{array}{l}0.074 \\
(1.077)\end{array}$ & 0.054 \\
\hline Hispanic & $\begin{array}{l}-0.076 \\
(0.927)\end{array}$ & 0.055 & $\begin{array}{l}-0.102 \\
(0.903)\end{array}$ & 0.055 & $\begin{array}{l}-0.142 * \\
(0.868)\end{array}$ & 0.056 \\
\hline Other & $\begin{array}{l}0.107 \\
(1.113)\end{array}$ & 0.070 & $\begin{array}{l}0.068 \\
(1.070)\end{array}$ & 0.070 & $\begin{array}{l}0.052 \\
(1.053)\end{array}$ & 0.071 \\
\hline \multicolumn{7}{|l|}{ Education (Less than $\mathrm{HS}=0$ ) } \\
\hline High School & $\begin{array}{l}-0.150^{* *} \\
(0.861)\end{array}$ & 0.055 & $\begin{array}{l}-0.149^{* *} \\
(0.862)\end{array}$ & 0.055 & $\begin{array}{l}-0.102 \\
(0.903)\end{array}$ & 0.056 \\
\hline Some College & $\begin{array}{l}-0.252 * * * \\
(0.777)\end{array}$ & 0.056 & $\begin{array}{l}-0.253^{* * *} \\
(0.776)\end{array}$ & 0.056 & $\begin{array}{l}-0.188 * * \\
(0.829)\end{array}$ & 0.058 \\
\hline Four Year Degree or More & $\begin{array}{l}-0.726^{* * *} \\
(0.484)\end{array}$ & 0.065 & $\begin{array}{l}-0.719 * * * \\
(0.487)\end{array}$ & 0.066 & $\begin{array}{l}-0.639 * * * \\
(0.528)\end{array}$ & 0.067 \\
\hline Age & $\begin{array}{l}-0.011^{* * * *} \\
(0.989)\end{array}$ & 0.002 & $\begin{array}{l}-0.011^{* * * *} \\
(0.989)\end{array}$ & 0.002 & $\begin{array}{l}-0.010 * * * \\
(0.990)\end{array}$ & 0.002 \\
\hline Children & $\begin{array}{l}-0.089^{*} \\
(0.915)\end{array}$ & 0.039 & $\begin{array}{l}-0.087^{*} \\
(0.917)\end{array}$ & 0.038 & $\begin{array}{l}-0.086^{*} \\
(0.918)\end{array}$ & 0.039 \\
\hline Observations & $1,543,473$ & & $1,543,473$ & & $1,543,473$ & \\
\hline
\end{tabular}

Note: Robust standard errors.

$* * * p<0.001, * * p<0.01, * p<0.05$

Eads, Griffin, and Tach 37 
Supplementary Table 3. Cox Proportional Hazard Analysis for Variables Predicting Dissolution for Subsamples of Young (age < 40 years) Married and Cohabiting Couples

\begin{tabular}{|c|c|c|c|c|}
\hline & \multicolumn{2}{|c|}{ Cohabiting } & \multicolumn{2}{|l|}{ Married } \\
\hline & \multirow{2}{*}{\multicolumn{2}{|c|}{$\begin{array}{c}\text { B } \\
\text { (Haz. Ratio) }\end{array}$}} & \multicolumn{2}{|l|}{$\begin{array}{c}B \\
(\text { Haz. Ratio) }\end{array}$} \\
\hline Liquid Assets (Homophilous=0) & & & & \\
\hline Female-Dominant & $\begin{array}{l}0.318^{*} \\
(1.374)\end{array}$ & 0.149 & $\begin{array}{r}0.276^{* * * *} \\
(1.318)\end{array}$ & 0.067 \\
\hline Male-Dominant & $\begin{array}{r}0.290 \\
(1.336)\end{array}$ & 0.149 & $\begin{array}{r}0.186^{* *} \\
(1.204)\end{array}$ & 0.064 \\
\hline No Holdings & $\begin{array}{l}0.387^{*} \\
(1.473)\end{array}$ & 0.155 & $\begin{array}{r}0.312 * * * \\
(1.366)\end{array}$ & 0.074 \\
\hline Illiquid Assets (Homophilous=0) & & & & \\
\hline Female-Dominant & $\begin{array}{r}0.165 \\
(1.179)\end{array}$ & 0.125 & $\begin{array}{r}0.365 * * * a \\
(1.441)\end{array}$ & 0.079 \\
\hline Male-Dominant & $\begin{array}{r}0.108 \\
(1.114)\end{array}$ & 0.127 & $\begin{array}{r}0.135 \\
(1.145)\end{array}$ & 0.073 \\
\hline No Holdings & $\begin{array}{r}0.215 \\
(1.240)\end{array}$ & 0.149 & $\begin{array}{r}0.472 * * * \\
\quad(1.603)\end{array}$ & 0.105 \\
\hline Unsecured Debt (Homophilous=0) & & & & \\
\hline Female-Dominant & $\begin{array}{r}0.045 \\
(1.046)\end{array}$ & 0.151 & $\begin{array}{r}0.448 * * * \\
(1.565)\end{array}$ & 0.065 \\
\hline Male-Dominant & $\begin{array}{r}0.088 \\
(1.092)\end{array}$ & 0.156 & $\begin{array}{r}0.447 * * * \\
(1.564)\end{array}$ & 0.069 \\
\hline No Holdings & $\begin{array}{r}-0.116 \\
(0.890)\end{array}$ & 0.156 & $\begin{array}{r}0.011 \\
(1.011)\end{array}$ & 0.060 \\
\hline Secured Debt (Homophilous $=0$ ) & & & & \\
\hline Female-Dominant & $\begin{array}{l}0.567 * \\
(1.763)\end{array}$ & 0.228 & $\begin{array}{r}0.031 \\
(1.031)\end{array}$ & 0.118 \\
\hline Male-Dominant & $\begin{array}{l}0.551^{*} \\
(1.735)\end{array}$ & 0.224 & $\begin{array}{r}0.040 \\
(1.041)\end{array}$ & 0.102 \\
\hline No Holdings & $\begin{array}{r}0.751 * * * \\
(2.119)\end{array}$ & 0.205 & $\begin{array}{r}0.269 * * * \\
\quad(1.309)\end{array}$ & 0.069 \\
\hline Observations & 61,524 & & 539,344 & \\
\hline
\end{tabular}

${ }^{a}$ Female-dominant couples are at a significantly higher risk of dissolution compared to male-dominant couples.

Note: Controls included in the model but not shown in table: net worth, income, relative income, employment, race/ethnicity, education, age, and children. Robust standard errors.

$* * * p<0.001, * * p<0.01, * p<0.05$ 